\author{
Kamila Ziółkowska-Weiss \\ Uniwersytet Pedagogiczny \\ im. Komisji Edukacji Narodowej \\ w Krakowie
}

\title{
Podróże motywacyjne a rozwój przedsiębiorczości w firmie na przykładzie niemieckiej i hiszpańskiej grupy pracowników
}

Coraz większa liczba międzynarodowych podróży biznesowych jest rezultatem postępującego procesu globalizacji gospodarki światowej, z którym wiąże się narastająca potrzeba bezpośrednich kontaktów między współpracującymi podmiotami. Turystyka biznesowa, określana także terminem podróże stużbowe, nie mieści się w klasycznej definicji turystyki odnoszącej się do wyjazdów w czasie wolnym. Podróże służbowe odbywane w ramach czasu poświęconego pracy niezupełnie spełniają także wymóg dobrowolności wyjazdu. Jednakże ze względu na liczbę międzynarodowych podróży odbywanych w celu załatwiania spraw zawodowych oraz ich powiązanie z bazą turystyczną Światowa Organizacja Turystyki zdecydowała się włączyć podróże służbowe w zakres turystyki, a osoby uczestniczące w takich wyjazdach określać jako turystów. We współczesnym pojmowaniu turystyki akceptuje się więc jej związki z pracą, czego przejawem są między innymi coraz częściej stosowane w literaturze naukowej określenia: workingtourists ('pracujący turyści') oraz touringworkers ('podróżujący pracownicy').

Celem niniejszego artykułu jest zweryfikowanie hipotezy mówiącej o tym, że podróże motywacyjne są najlepszym sposobem na podniesienie efektywności i wydajności pracowników oraz najskuteczniejszą formą integracji zespołu pracowniczego danej firmy. Krótko zostaną w nim scharakteryzowane zadania oraz zyski firmy, które realizowane są po odbytej podróży motywacyjnej. W artykule zostaną przedstawione również wyniki ankiet, które zostały przeprowadzone wśród pracowników dwóch grup: hiszpańskiej i niemieckiej, biorących udział w podróży motywacyjno-integracyjnej. Warto zaznaczyć, że zaprezentowane wyniki dotyczą zarówno kadry zarządzającej, jak i pracowników niższego szczebla, co pozwoli na porównanie i próbę odpowiedzi na pytanie, jakie oczekiwania wobec firmy mają poszczególni pracownicy. $\mathrm{Na}$ koniec zostanie udowodnione, że wyjazdy motywacyjne stanowią jedną $\mathrm{z}$ form dodatkowego wynagrodzenia pracowników za ich starania oraz są zachętą do dalszej efektywnej pracy, co z kolei wpływa na rozwój przedsiębiorczości w firmie. Dzięki nim buduje się więź między pracownikiem a firmą, ponadto wpływają one korzystnie na samoocenę pracownika, motywując go do większej aktywności w firmie.

\section{Turystyka związana $\mathrm{z}$ biznesem}

Turystykę biznesową dzieli się na: indywidualne podróże służbowe (np. dziennikarzy, polityków, biznesmenów), spotkania grupowe (np. kongresy, seminaria szkoleniowe), uczestnictwo w targach lub imprezach konsumenckich, podróże motywacyjne i turystykę korporacyjną (np. luksusowe rozrywki oferowane przez firmy najcenniejszym klientom lub przyszłym klientom 
w czasie prestiżowych wydarzeń kulturalnych czy sportowych) (Davidson 2007). Turystyka biznesowa to wyjazdy o charakterze zawodowym, podczas których osoby wyjeżdżające korzystają z podstawowych usług turystycznych, a w czasie wolnym zaspokajają potrzeby wypoczynku, poznania nowego miejsca, rozrywki i relaksu. Są to podróże odbywane przez pracowników i inne osoby w ramach ich pracy, obejmujące uczestnictwo w spotkaniach, konferencjach czy wystawach (Medlik 1995). Turystyka biznesowa bardzo często określana jest mianem branży MICE. Nazwa ta jest skrótem utworzonym od angielskich nazw podstawowych rodzajów podróży biznesowych. Są to:

- meetings ('spotkania'),

- incentives ('podróże motywacyjne'),

- conferences ('kongresy, szkolenia, konferencje'),

- events ('wystawy').

Współczesne podróże służbowe stały się jednym z podstawowych elementów sprawnego funkcjonowania różnych organizacji, w tym przedsiębiorstw rynkowych. Stanowią one także ważne narzędzie ich działalności marketingowej zarządzania personelem czy public relation. Stąd w ramach zjawiska turystyki biznesowej można wskazać takie formy, jak (Kurek 2007):

- indywidualne podróże służbowe,

- turystyka targowa (turystyka wystawowa),

- turystyka korporacyjna,

- turystyka konferencyjna (turystyka spotkań),

- turystyka motywacyjna.

Wymienione formy wielokrotnie się ze sobą przeplatają w ramach jednego wyjazdu. Bardzo często łączy się konferencje z wystawami, a wyjazdy motywacyjne z turystyką korporacyjną lub odwrotnie. Głównym tematem niniejszego artykułu są wyjazdy motywacyjne. Jest to stosunkowo nowa forma wynagradzania pracowników, która jednak w przeciągu kilku kolejnych lat bardzo się rozwinie.

Podróże motywacyjne mogą mieć charakter typowo wypoczynkowy, poznawczy, przygodowy itp. W zależności od specyfiki kulturowej państw mogą to być:

- krajowe lub zagraniczne podróże motywacyjne zgodnie z przedstawioną definicją, o wysokim standardzie, z niepowtarzalnym programem, trwające 3-7 dni,

- długie luksusowe wyjazdy jako nagroda dla najlepszych dystrybutorów, dilerów, hurtowników, bez udziału zwykłych pracowników firmy sponsorującej, za to z udziałem pionu kierowniczego,

- nagrodowe wyjazdy turystyczne dla pracowników do atrakcyjnych miejsc bez zasady wyjątkowości programu,

- wyjazdy szkoleniowo-rozrywkowo-integracyjne z programem budowania zespołu i udziałem psychologa w celu wyłonienia nieformalnych liderów,

- nagrodowe krótkie wyjazdy zagraniczne z udziałem członków rodziny pracownika,

- integracyjne wyjazdy kierowników firm kooperujących z firmą sponsorującą połączone z prezentacją zakładów produkcyjnych, procesu technologicznego w kraju sponsora i programem rekreacyjnym,

- wyjazdy szkoleniowe z elementami rekreacji i zabawy,

- luksusowe egzotyczne wyjazdy dla wąskiej grupy osób zarządzających firmą, razem z rodzinami (Socała 1999).

Podaje się na przykład, że incentivetravel to podróże pracowników, sprzedawców lub agentów opłacane przez przedsiębiorstwo w ramach nagrody za realizację odpowiedniej sprzedaży lub innych zadań, za wyróżniające osiągnięcia lub jako zachęta na przyszłość. Inne określenie tego zjawiska podaje organizacja Society of Incentive\&Travel Executives (SITE), według 
której podróże motywacyjne to narzędzie całościowego zarządzania do wykorzystywania wyjątkowych podróży w celu zmotywowania i(lub) nagrodzenia pracowników za ich pracę wykraczającą poza obowiązki i zbliżającą do osiągnięcia celów firmy (Socjała 1999).

$\mathrm{W}$ ostatnich latach rynek pracy podlega dynamicznym zmianom. W sytuacji, kiedy pracownicy zaczynają dyktować warunki, a pozyskanie wykwalifikowanej kadry staje się coraz trudniejszym zadaniem, pracodawcy zmuszeni są podejmować działania mające na celu zatrzymanie doświadczonych pracowników. W wielu wypadkach pozyskanie i wdrażanie nowego pracownika wymaga poniesienia większych nakładów niż lepsze zmotywowanie pracowników, którzy w danym przedsiębiorstwie pracują. Wiąże się to $\mathrm{z}$ wprowadzeniem zaplanowanego systemu motywacji.

Trudno utrzymać najlepszych i najbardziej wydajnych pracowników bez oferowania im dodatkowych profitów. Dlatego też coraz częściej szuka się innych metod motywowania pracowników. Popularne są rozbudowane systemy motywacyjne, przygotowywane każdorazowo na miarę, czyli w zależności od aktualnych potrzeb przedsiębiorstwa. Incentivetravel jest tutaj jedną z coraz popularniejszych metod motywowania pracowników. Już teraz powszechnie wiadomo, że jest to jedna z lepszych form podnoszenia wydajności zespołu, a w efekcie i zysku firmy. Jak twierdzą niektórzy przedsiębiorcy, jest to inwestycja, która się zwraca.

Badania wskazują, że dobrze zorganizowany wyjazd motywacyjny pozytywnie wpływa na postawę pracowników oraz na poprawienie wizerunku firmy w oczach zatrudnionych w niej ludzi. Zatem warto inwestować w taką formę integracji zespołu.

\section{Korzyści płynące z odbytej podróży motywacyjnej}

Zasadniczo wyjazdy motywacyjne spełniają dwojaką funkcję. W pierwszej kolejności powinny być nagrodą za dobrze wykonaną pracę. W drugiej, nie mniej ważnej, jak sama nazwa wskazuje, powinny stymulować pracowników do jeszcze lepszej i docelowo wydajniejszej pracy (Davidson 2007).

Imprezy integracyjne pomagają stworzyć lepszą atmosferę w miejscu pracy. Umożliwiają także poprawienie kwalifikacji zatrudnionych pracowników przez szkolenia czy konferencje połączone z aktywnym, integrującym ich wypoczynkiem. Relaks i rozrywka zmieniają obowiązkowe kursy w przyjemny i mile widziany przerywnik codziennej pracy. Zmiany, które zachodzą w zespole po tego typu szkoleniach, są wręcz namacalne dla pracodawców. Lepsza atmosfera, przyjaźniejsze podejście pracowników do siebie nawzajem, wzrost wzajemnego zaufania, większe zaangażowanie w sprawy firmy, dużo większe zgranie zespołów zadaniowych dają widoczny wzrost efektywności.

Jednym z ważniejszych zadań każdej imprezy integracyjnej jest budowanie zespołów, czyli team building. Ma ono na celu tworzenie więzi interpersonalnych, nie tylko o charakterze zawodowym, lecz również prywatnym. Program i zajęcia na wyjeździe integracyjnym mają uświadomić pracownikom, że pracują w jednej grupie, uczą się wtedy ze sobą komunikować, zdają sobie sprawę, że działają wspólnie i mogą liczyć tylko na siebie (Gaworecki 2007).

\section{Zyski dla firmy po odbytej podróży motywacyjnej}

Istnieje szereg korzyści, które czerpie firma ze zorganizowanego wyjazdu motywacyjnego dla swoich pracowników. Jeżeli program motywacyjny i imprezy zorganizowane są w sposób przemyślany, nie są one jedynie kosztowną fanaberią, ale inwestycją, dzięki której zyski firmy rosną. Mowa tu nie tylko o zyskach finansowych, ale także o integracji i zwiększeniu lojalności pracowników oraz ich motywacji do dalszej pracy. W tym miejscu nasuwa się pytanie o to, 
czy nagrodzenie pracownika wyjazdem integracyjnym jest lepszym prezentem od nagrody pieniężnej. Dla pracodawcy w ogólnym rozrachunku jest to niewątpliwie tańsza forma nagrody. Trudniej jest bowiem zrobić wrażenie na pracowniku nagrodą pieniężną, którą pracownik odnosi zawsze do swojego dochodu. Ponadto wyjazdy lepiej zapadają w pamięć. Gotówka zostaje zużyta na podstawowe potrzeby i jej otrzymanie jest szybko zapominane.

Kolejną korzyścią dla firmy jest zmotywowanie tych pracowników, którzy w wyjeździe nie wzięli udziału. Ich koledzy powracający z podróży i opowiadający o jej atrakcjach mogą zachęcić innych do cięższej pracy w celu zdobycia kolejnej podobnej nagrody. Firma ma więc korzyści, których nie odniosłaby, gdyby na przykład rozdała najlepszym pracownikom premie, ponieważ nagrodzeni nie byliby już tak chętni do opowiadania kolegom o nagrodzie.

Wyjazdy jako nagrody stawiają również pracodawcę w sytuacji korzystnej w stosunku do konkurencji, gdyż program wiąże pracownika z konkretną, swoją firmą. Jest to dość istotne, szczególnie teraz, w czasach emigracji ludzi do krajów Unii Europejskiej w poszukiwaniu pracy. Nagrody pieniężne nie odgrywają już tak silnej roli jak wizja spędzenia upojnych kilku dni w niezapomniany sposób. Warto więc taką formę gratyfikacji wprowadzać w firmach.

Podróż jako nagroda, oprócz przyczyniania się do osiągnięcia celów firmy, wiele ze swojej skuteczności zawdzięcza także temu, że zaspokaja niektóre z potrzeb pracownika. Na przykład, w odróżnieniu od innych nagród, ma wartość trofeum. Podnosi status społeczny, gdyż jej zdobywca jest odbierany nie tylko jako osoba osiągająca najlepsze wyniki w sprzedaży, lecz także jako jedna z niewielu osób, które przeżyły tak niezwykłe doświadczenia. Zwolennicy podróży motywacyjnych podkreślają, że każda nagroda zapewniająca nagradzanemu tego typu uznanie na długo pozostawia dobre wrażenia, co należy dodać do jej znaczenia motywującego.

Inną podkreślaną korzyścią dla pracownika jest to, że jego partnerzy i inni członkowie rodziny chętniej akceptują dodatkowy czas i wysiłek, który pracownik poświęca firmie w celu otrzymania nagrody. Jeśli członkowie rodzin są także zapraszani do udziału w podróży, to wówczas są bardziej tolerancyjni i godzą się na długie godziny, jakie ich partnerzy muszą spędzić w pracy, aby zasłużyć na nagrodę.

Warto zaznaczyć, że wyjazdy motywacyjne sprawiają, iż pracownicy czują się doceniani i rośnie w nich przekonanie o ich ważności. Imprezy motywacyjne to również doskonałe narzędzie w ręku kadry zarządzającej. Podczas integracji na takich wyjazdach mają okazję obserwować zachowanie swoich pracowników. Często wtedy można wyłonić liderów, a także zauważyć antypatie pracowników, co jest ważne przy tworzeniu dobrego zespołu.

Starannie zaplanowany, zorganizowany i zrealizowany projekt incentive to nieoceniona korzyść dla firmy, która inwestuje w entuzjazm i kreatywność ludzi - najważniejszego czynnika sukcesu każdej firmy. Dlatego tak ważny jest odpowiedni wybór miejsca, rodzaju atrakcji oraz organizatora takiego wyjazdu.

\section{Analiza i wyniki ankiet przeprowadzone na niemieckiej i hiszpańskiej grupie pracowników} W artykule została przedstawiona opinia osób uczestniczących w podróży motywacyjnej oraz wyniki ankiet, które zostały przeprowadzone wiosną 2011 roku w Zakopanem. Główne pytania w ankiecie dotyczyły tego, czy wyjazdy tego typu są najlepszym sposobem na podniesienie efektywności i wydajności pracowników oraz czy są one najskuteczniejszą formą integracji zespołu pracowniczego danej firmy. Ankietowani pytani byli również o to, czy według nich zaplecze turystyczne w Polsce jest odpowiednio przygotowane na przyjęcie i zaspokojenie wszystkich niezbędnych potrzeb związanych z organizacją podróży motywacyjnych. 
Warto zaznaczyć, że ankiety przeprowadzone zostały w dwóch grupach. Jedną z nich stanowili pracownicy, którzy zajmują w firmie stanowiska niższego szczebla, drugą natomiast kadra zarządzająca. Pierwsza grupa reprezentowana była przez 35 osób z Niemiec, a druga przez 15 osób z Hiszpanii. Dzięki odpowiedziom uzyskanym przez respondentów zauważyć można, że w zależności od piastowanego stanowiska w firmie przekonania w sprawie wynagradzania pracowników oraz ocena funkcjonowania firmy jest zróżnicowana. Wyniki uzyskanych badań dotyczących podróży motywacyjnych przedstawiono w tabeli 1 .

Tab. 1. Wyniki ankiety przeprowadzonej w dwóch grupach pracowników

\begin{tabular}{|c|c|c|c|c|c|c|c|}
\hline \multirow{2}{*}{ Lp. } & \multirow{2}{*}{ Pytanie } & \multicolumn{2}{|c|}{$\begin{array}{c}\text { Grupa } \\
\text { niemiecka }\end{array}$} & \multicolumn{2}{|c|}{$\begin{array}{c}\text { Grupa } \\
\text { hiszpańska }\end{array}$} & \multicolumn{2}{|c|}{$\begin{array}{c}\text { Obie grupy } \\
\text { lącznie }\end{array}$} \\
\hline & & $\begin{array}{l}\text { Tak } \\
(\%)\end{array}$ & $\begin{array}{l}\text { Nie } \\
(\%)\end{array}$ & $\begin{array}{l}\text { Tak } \\
(\%)\end{array}$ & $\begin{array}{l}\text { Nie } \\
(\%)\end{array}$ & $\begin{array}{l}\text { Tak } \\
(\%)\end{array}$ & $\begin{array}{l}\text { Nie } \\
(\%)\end{array}$ \\
\hline 1. & $\begin{array}{l}\text { Czy uważa Pan(i), że wyjazdy } \\
\text { motywacyjne są najlepszym sposobem } \\
\text { na podniesienie efektów i wydajności } \\
\text { pracowników w firmie? }\end{array}$ & 77 & 23 & 100 & 0 & 84 & 16 \\
\hline 2. & $\begin{array}{l}\text { Czy uważa Pan(i), że uczestnictwo } \\
\text { w wyjeździe motywacyjnym wpływa } \\
\text { na lepszy status i prestiż wśród } \\
\text { pracowników? }\end{array}$ & 69 & 31 & 93 & 7 & 76 & 24 \\
\hline 3. & $\begin{array}{l}\text { Czy uważa Pan(i), że nagrodzenie } \\
\text { pracownika wyjazdem motywacyjnym } \\
\text { jest lepszym prezentem od nagrody } \\
\text { pieniężnej? }\end{array}$ & 69 & 31 & 87 & 13 & 74 & 26 \\
\hline 4. & $\begin{array}{l}\text { Czy uważa Pan(i), że istnieje obawa } \\
\text { wśród pracowników, że mogą oni } \\
\text { po wyjeździe motywacyjnym stracić } \\
\text { wiarę w firmę, motywację i chęć } \\
\text { do dalszej pracy? }\end{array}$ & 6 & 94 & 7 & 93 & 6 & 94 \\
\hline 5. & $\begin{array}{l}\text { Czy uważa Pan(i), że wyjazdy } \\
\text { integracyjne służą technikom } \\
\text { budowania efektywnego zespołu? }\end{array}$ & 86 & 14 & 87 & 13 & 86 & 14 \\
\hline 6. & $\begin{array}{l}\text { Czy uważa Pan(i), że po odbytej } \\
\text { podróży motywacyjnej zdolności } \\
\text { komunikacyjne między pracownikami } \\
\text { w firmie są lepsze? }\end{array}$ & 80 & 20 & 93 & 7 & 84 & 16 \\
\hline 7. & $\begin{array}{l}\text { Czy uważa Pan(i), że udział } \\
\text { w wyjeździe motywacyjnym kształtuje } \\
\text { lojalność pracowników wobec firmy? }\end{array}$ & 54 & 46 & 87 & 13 & 64 & 36 \\
\hline 8. & $\begin{array}{l}\text { Czy uważa Pan(i), że pracownicy firmy, } \\
\text { którzy nie wzięli udziału w wyjeździe } \\
\text { motywacyjnym, będą mniej } \\
\text { zmotywowani do pracy niż osoby } \\
\text { uczestniczące w wyjeździe? }\end{array}$ & 89 & 11 & 100 & 0 & 92 & 8 \\
\hline
\end{tabular}

Źródło: opracowanie własne. 
Jak wynika z przeprowadzonych badań, kadra zarządzającą jest przekonana o tym, że wyjazdy motywacyjne są najlepszym sposobem na podniesienie efektów i wydajności pracowników w firmie. Tak odpowiedzieli wszyscy reprezentujący grupę hiszpańską, natomiast w grupie niemieckiej z poglądem tym zgodziło się $77 \%$ osób.

Podobnie przedstawiają się wyniki dotyczące integracji zespołu pracowniczego danej firmy. Na pytanie o to, czy po odbytej podróży motywacyjnej zdolności komunikacyjne między pracownikami są lepsze, tylko 1 osoba spośród 15 osób z Hiszpanii odpowiedziała, że nie, podczas gdy w grupie niemieckiej negatywnych odpowiedzi było aż 7. Zdaniem 2 osób z Hiszpanii i 5 z Niemiec wyjazdy integracyjne nie służą budowaniu efektywnego zespołu.

Na pytania dotyczące przywiązania pracowników do danej firmy odpowiedzi poszczególnych grup również były zróżnicowane. Hiszpanie twierdzili, że biorąc udział w wyjeździe motywacyjnym, kształtuje się lojalność pracowników wobec firmy. Tak odpowiedziało $87 \%$ z nich, podczas gdy w grupie niemieckiej lojalność pracowniczą deklarowało tylko 19 osób, co stanowiło $54 \%$ ogółu.

Dużą dysproporcję między grupą niemiecką a hiszpańską można również zauważyć w pytaniach o wzrost status i prestiżu wśród pracowników po odbytej podróży motywacyjnej oraz o formę wynagradzania pracowników. W grupie z Niemiec 11 osób twierdziło, że nagroda pieniężna jest lepszym prezentem i większym docenieniem pracownika niż upominek w postaci podróży motywacyjnej. Te same osoby z Niemiec poświadczyły w swoich ankietach, że uczestnictwo w wyjeździe motywacyjnym w żaden sposób nie wpływa na wyższy status i prestiż wśród pracowników. Innego zdania są Hiszpanie. Wszyscy oni twierdzą, iż pracownicy firmy, którzy nie wzięli udziału w wyjeździe motywacyjnym będą mniej zmotywowani do pracy niż osoby w nim uczestniczące. Według nich prestiż wśród pracowników jest zdecydowanie wyższy po nagrodzeniu zatrudnionych uczestnictwem w wyjeździe motywacyjnym. Uważają oni również, że podwładni bardziej doceniają taką formę nagrodzenia niż bonus w postaci dodatkowych pieniędzy. Wyjątek w tej grupie stanowią dwie osoby, które w tym wypadku odpowiedziały inaczej. Były to osoby, które po raz pierwszy uczestniczyły w wyjeździe integracyjnym, a w firmie pełnią niższe funkcje. Osoby te zaznaczyły w ankietach, że nie zajmują w firmie stanowisk dyrektorskich, a jedynie stanowiska administracyjne.

\section{Interpretacja wyników}

Wyniki badań, choć różne w obu grupach, pozwoliły zweryfikować postawioną na początku artykułu hipotezę. Jednoznacznie wskazały one, że podróże motywacyjne są rozwijającą się dziedziną turystyki i stanowią nieodzowną część dobrze funkcjonującej korporacji. Uczestnicy podróży tego typu rozwijają swoje zdolności interpersonalne, uczą się współdziałania w grupie oraz podstawowych zasad skutecznej komunikacji, niezbędnych do sprawnego funkcjonowania firmy i zespołu. Wyjazdy integracyjne zacieśniają relacje pomiędzy pracownikami, pozytywnie wpływając na ich zaangażowanie oraz efektywność pracy. Są też świetnym sposobem na zintegrowanie nowych pracowników z działającym już zespołem.

Jak wykazały przeprowadzone ankiety, wyjazdy motywacyjne stanowią jedną z form dodatkowego wynagrodzenia pracowników za ich starania oraz są zachętą do dalszej efektywnej pracy. Budują więź między pracownikiem a firmą, dodatkowo motywują pracownika do większej aktywności.

Zastosowane narzędzia badawcze wykazały również, że Polska stanowi odpowiednią bazę na organizację imprez integracyjnych. Jest ona doskonałym miejscem, oferującym góry, morze, jeziora oraz rozległe zielone tereny. Dzięki rozwojowi turystyki w Polsce oraz kładzeniu dużego nacisku na jej promocję, Polska w oczach obcokrajowców z roku na rok staje się coraz bardziej atrakcyjniejszym miejscem dla turystów. 
Uzyskane wyniki ankiet potwierdziły również pogląd, że w sprawie funkcjonowania firmy wyjazdy są inaczej oceniane przez kadrę zarządzającą, a zupełnie inaczej przez pracowników korporacji. Ci pierwsi przekonani są o tym, że warto inwestować w pracownika, nagradzając go wyjazdem motywacyjnym, natomiast zatrudnieni chętniej widzieliby dodatkowy bonus w postaci pieniędzy niż wyjazdu. Dyrektorzy przekonani są o tym, że po odbytej podróży stosunek ich pracowników do firmy się pogłębia, stają się oni bardziej lojalni w stosunku do niej oraz czują się bardziej z nią związani. Wielu pracowników twierdzi, że uczestnictwo w podróży motywacyjnej w żaden sposób nie kształtuje w nich poczucia lojalności i przywiązania do firmy oraz nie wpływa na ich wydajność i zaangażowanie w pracy.

Kierujący personelem w firmie przekonani są o lepszej komunikacji między nimi oraz o pogłębianiu więzi i przyjaźni pracowników, które rodzą się po odbytej podróży motywacyjnej. Takimi dużymi optymistami w tej kwestii nie są niestety wszystkie przebadane osoby z grupy podwładnej zarządowi.

Wydawałoby się, że podróży i pracy nie da się pogodzić, ponieważ albo ktoś jest na urlopie, albo pracuje. Wykonywanie tych czynności równocześnie jest po prostu niemożliwe. I owszem, tak właśnie jest. Ale kto powiedział, że nie da się połączyć podróży i pracy zawodowej?

Podróże motywacyjne są jednym ze sposobów na podniesienie efektywności i wydajności pracowników oraz najskuteczniejszą formą integracji zespołu pracowniczego danej firmy. A zatem są doskonałym rozwiązaniem łączącym wypoczynek z pracą zawodową.

Najważniejszym kapitałem firmy są jej pracownicy, którzy mają coraz większe poczucie swej niezależności, przede wszystkim ze względu na posiadane kwalifikacje. Utrzymanie ich w organizacji nie jest łatwe, chociażby ze względu na kuszenie ich przez konkurencję. Dlatego też tak ogromne znaczenie mają systemy motywacyjne, których zadaniem jest sprawić, aby pracownik czuł się w firmie dobrze, dawał z siebie jak najwięcej i nie chciał się z nią rozstawać. Jest wiele sposobów motywowania ludzi do podejmowania określonych działań czy rzetelnego i efektywnego wykonywania powierzonych obowiązków. Niewątpliwie najwięcej zalet mają właśnie podróże motywacyjne. To właśnie na takim wyjeździe pracownicy świetnie się bawią, relaksują i zwiedzają ciekawe zakątki kraju czy zagranicy. To właśnie wtedy zachodzi najszybsza i najskuteczniejsza integracja grupy pracowników, którzy mogą nie tylko lepiej się poznać, wykonując wspólne zadania, ale także już na zawsze będą mieli wspólne wspomnienia i tematy do rozmów. I to właśnie wtedy pracownicy uczą się nowych rzeczy, zdobywają umiejętności i podnoszą swoje kwalifikacje. Warto się przekonać, że ten rodzaj turystyki, którym są podróże motywacyjne, bardzo się rozwinie, a oferty takich wyjazdów będą w katalogach większości biur podróży.

\section{Literatura}

1. Alejziak W., 1992, Turystyka w obliczu wyzwań XXI wieku, Albis, Kraków.

2. Davidson R., 2007, Turystyka biznesowa: konferencje, podróże motywacyjne, wystawy, turystyka korporacyjna, Polska Organizacja Turystyki, Warszawa.

3. Gajewski M., Łopuszański S., Opowicz P., Socała J., Świątecki A., 1999, Incentive po Polsku, Warszawa.

4. Gaworecki W., 2007, Turystyka, PWE, Warszawa.

5. Gaworecki W., Makać A. (red.) 2007, Turystyka biznesowa, Wydawnictwo Ava, Gdańsk.

6. Jędrzejczyk I., 2000, Nowoczesny biznes turystyczny. Ekostrategia w zarzadzaniu firma, Wydawnictwo Naukowe PWN, Warszawa. 
7. Kozłowski T., 2007, Bariery rozwoju podróży motywacyjnych w turystyce biznesowej [w:] Turystyka biznesowa, W. Gaworecki, A. Makać A. (red.), Wydawnictwo Ava, Gdańsk, s. 84-90.

8. Kulesza I., Łopaciński K., 2008, Turystyka biznesowa w Polsce, Mice Poland, Warszawa.

9. Medlik S., 1995, Leksykon podróży, turystyki, hotelarstwa, Wydawnictwo Naukowe PWN, Warszawa.

10. Sikora J., Wartecka-Ważyńska A., 2007, Turystyka motywacyjna instrumentem zarzadzania zasobami ludzkimi w przedsiębiorstwie [w:] Turystyka biznesowa, W. Gaworecki, A. Makać (red.), Wydawnictwo Ava, Gdańsk, s. 76-83.

11. Socała J., 1997, Podróże w interesach to dobry interes, „Rzeczpospolita” z 10 grudnia.

12. Socała J., 1998, Incentive po polsku, „Super Tramp”, nr 2(4).

13. Socała J., 1999, Dobre prognozy dla turystyki motywacyjnej i biznesowej Targi - EIBTM - Genewa 1999, „TTG Poland”, nr 8.

14. Socała J., 1999, Podróże motywacyjne i nowe tysiąclecie, „Polska Gazeta Turystyczna”, nr 10.

15. Socała J., 2003, Nowe rozdanie: podróże motywacyjne, „Aktualności Turystyczne”, nr 3.

16. Szwichtenberg A., 2007, Fenomen podróży motywacyjnych w Polsce i na świecie [w:] Turystyka biznesowa, W. Gaworecki, A. Makać (red.), Wydawnictwo Ava, Gdańsk, s. 65-75.

\section{Incentive trips and entrepreneurship development in a company based on the example of German and Spanish employees}

The aim of this article is to verify a hypothesis stating that incentive trips are the best mean to raise efficiency and productivity of employees, and it is the most effective method to integrate a team of employees in a given company. This kind of trips is one of the best ways to boost effectiveness of the employees, which leads to profits increase of the company. This paper defines the goals, tasks and profits of the company, which are defined and delivered after the incentive trip. The data presented includes the outcomes of surveys that have been conducted in Spanish and German groups that took part in a motivational and incentive trip. It is worth noting that the presented results will concern both the management team and the employees of a lower level, which will enable to compare and analyse each employee's expectations towards their company.

Finally, the article proves that incentive trips are one of the ways to additionally reward employees for their efforts and are also a way to encourage them to perform more effectively in their job, which in turn influence the entrepreneurship development in the company. The trips help to build a bond between an employee and his company, and additionally, such trips positively influence the employee's self-esteem, motivating him to be more active in his work. 